\title{
RESEARCH ON THE RELAY PROTECTION SYSTEM OF MICRO-GRID
}

\author{
Zhaoyun Zhang, Wei Chen, Zhe Zhang
}

Original scientific paper In this paper, the necessity of the protective relay of the micro-grid is described as the anti-islanding protection and Low Voltage Ride Through (LVRT), and the fault characteristics of the renewable energy sources are analysed. The applicability of over-current protection, distance protection, differential protection, pilot protection, voltage protection and frequency protection is also analysed. Three novel solutions of protection have been proposed and discussed in this paper. After the stability of MG with external faults and internal faults is analysed, the protection configuration principle of micro-grid is proposed.

Keywords: Micro-grid; protection relay; fault characteristic; PCC; Wide-area protection relay

\section{Istraživanje sustava zaštite releja mikro-rešetke}

Izvorni znanstveni članak

U radu se potreba zaštitnog releja mikro-rešetke (MG) opisuje kao anti-islanding zaštita i Low Voltage Ride Through (LVRT) te se analiziraju karakteristike greške obnovljivih izvora energije. Također se analizira primjenljivost zaštite od preopterećenja, zaštite udaljenosti, zaštite diferencijala, zaštite pilot uređaja, zaštite napona i zaštite frekvencije. Predlažu se i razmatraju tri nova rješenja zaštite. Nakon što se uspostavila stabilnost MG poslije analize vanjskih i unutarnjih grešaka, predložen je princip konfiguracije zaštite mikro-rešetke.

Ključne riječi: mikro-rešetka; zaštitni relej; karakteristika greške; PCC; zaštitni relej širokog područja

\section{Introduction}

In recent years, the distributed generation (DG) and the Micro-grid (MG) system, represented by photovoltaic generation and wind power generation, have received more and more attention from researchers [1, 2]. Since different countries focus on different aspects of $\mathrm{MG}$, there is no universal definition to the concept of $\mathrm{MG}$ all over the world. The most widely accepted definition is given by the Consortium for Electric Reliability Technology Solutions (CERTS) of US, which states that one of the key features of the $\mathrm{MG}$ is its capability to raise the utilization rate of new energy sources and to enhance the power supply reliability of critical loads.

Quite some research has been done on the MGs in China $[3 \div 6]$ and a series of demonstrative projects have been deployed in DongFushan Island of Zhejiang province and ZhangBei of Hebei province [7]. The relay protection of $\mathrm{MG}$ is different from that of conventional power distribution network, and shall adapt to the uniqueness of MG: (1) multiple distributed generations are installed in the MG, so the current in the circuit can flow in two directions, making up the defects of conventional distribution network which can only support single-end power supply; (2) most of the micro power sources are accessed into the network by the inverter. The access of large amount of power electronics devices will cause new faults that do not exist in conventional distribution network; (3) MG can operate in both the gridconnected mode or in the islanded mode. The relay protection must be able to respond to the faults inside the MG in both operating modes and to sense the faults in the main grid in grid-connected mode with high selectivity, speed, sensitivity and reliability. The above mentioned unique features of the $\mathrm{MG}$ pose great challenges to relay protection $[8,9]$.

In the meantime, the new energy sources in the MG, which promises the function of low voltage ride through
(LVRT) and anti-islanding protection, also ensures a more stable operation of the MG. The LVRT refers to the capability of wind turbine generator set to operate in gridconnected mode uninterruptedly when the voltage dips at the connection point due to network faults or disturbance [10]. When the fault occurs outside of the $M G$, it is required that the protective relay device should isolate the fault point and recover network voltage within time limit so as to guarantee that the generator set can ride through the low voltage successfully and the MG needs not to operate off the grid. On the other hand, if the relay protection fails to isolate the fault quickly when faults occur within the MG, making the MG operate under low voltage for so long a time as to exceed the low voltage ride through capability of the generator, the new energy sources generator set will have to be disconnected.

The islanding is a new phenomenon that emerges with more and more new energy sources being connected into the electrical grid. The national and international standards (IEEE Std. 929 $\div 2000$ and GB/T 19939-2005 for example) have stated that all the photovoltaic inverters shall have the anti-islanding protection function and also have given the maximum allowed tripping time of inverter when the grid is power off [12]. It is required that the anti-islanding protection shall trip off the new energy sources within $2 \mathrm{~s}$, except when the severe overvoltage occurs, which shall be tripped off within $0,1 \mathrm{~s}$. If when the fault occurs within $\mathrm{MG}$ the relay protection successfully trips off the fault and restores the grid within 3 power frequency cycles, the anti-islanding protection will not act and MG can continue to operate in grid-connected mode; in contrast, if the relay protection acts slowly, the antiislanding protection will act before hand to trip off new energy sources or to make the $\mathrm{MG}$ operate in islanded mode.

Therefore, from the perspective of low voltage ride through and anti-islanding protection, the rapid response of protective relay devices is helpful to enhance the 
reliability of MG. Domestic and foreign researchers have made extensive studies on the relay protection of MG [13 $\div$ 18]. Ref. [8] proposed to use the negative sequence and zero sequence current protection to reflect the asymmetry and grounding fault in MG. In [14], a protection scheme using digital relays with a communication network is proposed for the protection of the MG system. The increased reliability of adding an additional communication line to form a closed information loop is explored. In [15], the authors detailed the assignment of two parameters which are critical for proper operation of a MG protection system. The first parameter, the fault current coefficient, represents the fault current supplied by any DG to any point inside the network whereas the second parameter is the adjustment of relay hierarchy for selective operation of relays. The automated assignment of these parameters serves the notion of self-operating MG protection system. Ref. [17] investigates the efficiency of under/over frequency relays for protection of distributed synchronous generators considering islanding detection and frequency-tripping requirements. In Ref. [18], the authors proposed faulted section detection using time over current protective relays. Ref. [19] proposed a laboratory $\mathrm{MG}$ protection system implemented using an industrial computer. However, the hardware platform based on rapid data acquisition is complicated and costly. Ref. [20] proposed a communication-free low voltage inverse time overcurrent protection scheme (UAITOC). However, this system will not function correctly in some cases when the new energy sources faults cannot be located by the current magnitude. Ref. [21] proposed the branch directional variation protection of $\mathrm{AC}$ MG. Ref. [22] proposed to use the hierarchical compromise scheme to resolve the challenges brought by the MG to the relay protection of distributing network. One common problem with these schemes is that they are proposed for one specific MG and thus cannot be applied universally. Therefore, it is necessary to conduct a comprehensive analysis of the relay protection of $\mathrm{MG}$ based on a thorough study of the fault features of the MG.

Instead of building special relay protection system, most of the demonstrative projects mentioned above still use the automation and protection devices designed for common distribution power system. The MG without relay protection system will fail to trip the internal and external fault effectively, which may cause the antiislanding protection of new energy sources to act. Even worse, if the new energy sources do not have the function of low voltage ride through, the new energy sources will be shut down immediately when internal and external faults occur. The action of anti-islanding protection or the shutdown of new energy sources will affect the operation of the MG, which goes against our intention to enhance the reliability by $\mathrm{MG}$.

Based on a thorough study of the fault features of new energy sources, the paper proposes three $\mathrm{MG}$ protection schemes according to the scale of the MG and discusses the stability of MG in each scheme.

\section{Fault features of new energy sources generators and protection adaptivity 2.1 Fault features of single supply}

MG has multiple type micro-powers, such as: photovoltaic power generator [23], wind power (including double-fed induction generator and direct-driven wind turbine generators) [24], micro-turbine generator [25], fuel cell [26], BESS [27], diesel generators, etc.

Depending on the way that micro power sources are connected into the grid, the power supply within $\mathrm{MG}$ can be divided into three categories:

The first category of new energy sources is connected into the network by rotating machines and converters. The representative for this kind of new energy sources generating system is the doubly-fed induction generating system.

The second category of new energy sources is connected into the network merely by converters. The major applications of this kind of new energy sources include direct-drive wind power generation system, photovoltaic power system, battery, micro gas turbine, etc.

The third category of energy is connected into the network merely by rotating machines. The major application of this kind of new energy sources is the diesel engine system. We will not elaborate on the fault features of this kind of new energy sources since it is similar to the main grid.

\subsubsection{Fault features of the first kind of new energy sources}

This kind of new energy sources is mainly used in the doubly-fed induction generating system. The fault features of this kind of new energy sources are radically different from those of conventional generators. The fault current is high, and in the early fault period there is the attenuating non power frequency component.

1) Whether the Crowbar circuit pickup or not will affect the strength of fault current.

2) After the Crowbar circuit acts, the frequency of the output current from generating system is similar to the frequency of the rotor rather than to the power frequency. At this time, the directional element which calculates according to power frequency cannot accurately reflect the fault. The component will be completely attenuated within $200 \mathrm{~ms}$.

3) Crowbar circuit parameter (mainly the parameter of resistant) determines the features of fault current, such as the magnitude and attenuation time, etc.

\subsubsection{Fault features of the second kind of new energy sources}

The second kind of new energy sources is connected into the network merely by converters. The majority applications of this kind of new energy sources include direct-drive wind power generation system, photovoltaic power system, battery, micro gas turbine, etc. Through the simulation and theoretical analysis of various types of faults, we come to the following conclusion:

1) The direction of the power output from inverter can accurately reflect fault type in all cases.

2) A short transient occurs during the fault period, and 
in the transient process a harmonic component exists.

3) A short period after the fault, the inverter output approaches toward stable state. The steady-state value of short circuit current is approximate to the rated current and the exact amount depends on the inverter controlling strategy.

4) The duration and the peak value of the transient process is subject to a number of factors, including the DC bus capacitance, outer-loop power parameter, input power, etc.

5) Whether it is a single phase fault, two-phase fault, or three-phase fault, the current for each fault is similar. Therefore, it is impossible to identify the faulty phase by current.

6) Due to the clipping effect of inverter, we cannot determine the distance of the fault by the intensity of the current.

Generally speaking, we use the fundamental current component to compute the short circuit current in relay protection. In fast protection, the process from starting the algorithm to sending the tripping command takes $20 \mathrm{~ms}$, about one power frequency cycle. Therefore, the effect of the peak fault current and the harmonic current can be neglected, and the photovoltaic system can be simplified in computing short circuit current. The photovoltaic system adopting the voltage source inverter controlling mode can be seen as the current source when computing short circuit current.

\subsection{Fault characteristics of MG network}

The features of the faults that occur in MG network are:

1) Whether the MGs are operating in grid-connected or in islanded mode, the new energy sources generation output features conform to the abovementioned single power source fault features.

2) Multiple sources are distributed in the MGs, making it possible for the current to flow in two directions. This is one of the major differences between MGs and conventional distribution network.

3) After being connected to the grid, the start-up and shutdown of the new energy sources generation system will severely affect the short circuit current of the fault. The diversified operation modes of new energy sources generators determine the complexity of the overcurrent protection setting.

4) In grid-connected and in islanded operation mode, the short circuit current in the places where protection is installed differs dramatically.

5) The difference in the low voltage ride through capability of new energy sources will affect the action of protection.

6) The configuration of the anti-islanding protection of new energy sources will affect the operation of MGs to a great extent.

7) The multi-terminal power inside the MG will have great effect on the overcurrent protection setting. When the short circuit occurs downstream the added distribution power, it will extend the protection range downstream. At this time, if the capacity of the distribution power is large enough, a misoperation will occur. The protection range of the timed fast trip at upstream of the distribution power system will shrink, which may cause maloperation when the capacity of the distribution power is large enough. When the short circuit occurs at upstream the added distribution power, the reverse current may occur, which will cause misoperation.

\subsection{Protection adaptability analysis}

The commonly used protections in the electrical grid include overcurrent protection, distance protection, differential protection, pilot protection, voltage protection, frequency protection, etc. Not all these protections can be applied to the MG due to the distinguishing characteristics of the micro power fault and the special structures of the MG.

\subsubsection{Overcurrent protection}

The overcurrent protection is the most commonly used protection in distribution network. But it can only be used as the backup protection rather than the main protection for MG for the following reasons

a) MG has multiple micro-power, the current flow can be bi-directional, the protection relay of the traditional Low Voltage (LV) system is considered single-ended power supply, unable to adapt to multiport power condition.

b) Since most of the new energy sources generating systems are equipped with current limiting devices, the fault current only lasts for a short period of time. And it is beyond the capability of overcurrent protection to trip the fault in a relatively short period of time.

c) The MG can be operated in grid-connected and in islanded mode, and the short circuit current under these two scenarios differs greatly. Adopting the overcurrent protection cannot ensure the selectivity, speed, sensitivity and reliability of protection under both scenarios.

d) The start-up and the shut-down of the new energy sources generating system within MGs will have great effect on the short circuit current. The diversity of the operation modes of new energy sources determines the complexity of the overcurrent protection setting.

e) For DFIG, after crowbar circuit act, the frequency of the output current of generator approximately equal to the rotor frequency, no longer equal to the rated frequency, then the power direction component which is calculated with rated frequency will not correctly reflect the failure.

\subsubsection{Distance protection}

Distance protection is the main protection for the 66 $\mathrm{kV}$ and above voltage, and for some of the $35 \mathrm{kV}$ system. But the distribution line of the $\mathrm{MG}$ is not long in most cases, which is unfavorable for the setting, so the distance protection is not applicable to the $\mathrm{MG}$ 


\subsubsection{Variable quantity protection}

The variable quantity protection is mainly used to increase the action speed of the $66 \mathrm{kV}$ and above voltage. But since most of the new energy sources generators in the $\mathrm{MG}$ are equipped with current limiting module devices, the quantity change value will be unable to reflect the real conditions of the fault, making it inappropriate for $\mathrm{MG}$ protection.

\subsubsection{Voltage protection and frequency protection}

The voltage protection and frequency protection are rarely used alone in the main grid. They are mainly used in the stability control equipment. Considering the need of anti-islanding, they can be used as the main protection at the network tie point

\subsubsection{Differential protection}

Differential protection has the advantage of fast action. It can act as quickly as within $5 \mathrm{~ms}$. The threshold of differential protection can be easily rectified, and it can be adapted to both the grid-connected operation mode and islanded operation mode, making it appropriate for the protection of MG. The disadvantage of differential protection is its high requirement for communication channels.

\subsubsection{Pilot protection}

Pilot protection adopts the two-end power direction rather than the current threshold as the protection criteria; therefore it can be applied to MG. In the meantime, the pilot direction protection does not require as much for communication channels as differential protection. It can use the multiplexed channel, public communication network channels, or even the wireless communication channels. However, the pilot protection does not apply to the MG with doubly-fed induction generators.

\section{Protection structure for MG}

The relay protection system for the MG can be divided into two parts: the protection for the connection point and the protection within MG.

It is essential to configure protection at the connection point $(\mathrm{PCC})$ regardless of the types of $\mathrm{MG}$, because the PCC protection provides the last resort of protection for the operation of main grid. The PCC protection configuration includes overcurrent protection, anti-islanding protection (voltage protection and frequency protection) and anti-back flow protection.

The protection devices such as fuse are installed within the MG according to the specific conditions of MG. Different protection configuration schemes can be deployed depending on the scale and importance of the $\mathrm{MG}$, include the wide area protection scheme, the distribution protection scheme, and the protection relying on primary equipment, etc.

\subsection{Wide area protection scheme}

In the wide area protection scheme, a central unit is used to implement the function of wide area protection and the intelligent remote terminal units are installed onsite to implement the function of real-time data collection and backup protection. The solution applies to the relatively high importance, larger MGs, usually important $10 \mathrm{kV} \mathrm{MG}$, while according to the degree of importance and the communication channel's availability, a single central unit and single process-layer-network, single central unit and dual process-layer-network, and dual central unit, dual process-layer-network and other configurations.



The structure of the wide-area protection scheme is illustrated in Fig. 1. This scheme is constituted by the following equipment:

1) Central unit, which is responsible for the protection of distribution lines and buses within the MG. It conducts the computation of main protection logic based on the data received from on-site units, and then sends controlling commands according to the 
computation results.

2) Intelligent remote terminal, which is mainly responsible for the acquisition of $\mathrm{AC}$ signals, the information of on-site circuit breakers and switch bars, and the controlling commands given by the central unit. The intelligent terminal is also equipped with the backup protection (compound voltage overcurrent protection for most of the time). In the meantime, the intelligent remote terminals can also implement the functions of telemetering, telesignaling, tele-regulating, tele-controlling, and equipment operation condition monitoring, etc.

3) The sub-station communication unit (optional) concentrates the data from all the devices in the MG and forward the information to the central station or local monitoring computer.

There are 2 types of communication involved in the wide area protection of MG: the communication between process level and the communication between master station and remote station. On the process level, the wide area protection is based on the complete 61850 communication architecture, including the SMV protocol and GOOSE protocol. The communication of process level can adopt the networking mode, or the point-topoint mode between intelligent terminal and central unit. The wide area protection involves three kinds of network services, which are SMV, GOOSE and time synchronization network, each of which can use a separate network, or share a common network. In practical applications, the IEEE1588 \& Synchronous Ethernet technologies are adopted to build a shared network for SMV, GOOSE and time synchronization, and optimized data flow distribution is achieved by using VLAN.

On the communication level of master stations and remote stations, the $\mathrm{MG}$ protection systems use by IEC103 and IEC61850 protocol through the Ethernet and RS485 serial communication channels.



Figure 2 MG system protection operation time diagram

The wide area protection scheme includes various kinds of protection, including the differential main protection, differential backup protection, and overcurrent protection, etc. The time limit matching of the protection is shown in Fig. 2. When the fault occurs within the protection range, the pilot protection, which acts as the main protection in the system, will detect the fault in 20 $\mathrm{ms}$ and give tripping order. If the fault lasts for more than $500 \mathrm{~ms}$, the wide area backup differential protection will act to resolve the circuit breaker malfunction and communication failure. If the fault continues to exist after $1000 \mathrm{~ms}$, according to the principle of time coordination, the overcurrent protection will act from stage to stage until isolating the malfunctioning equipment completely.

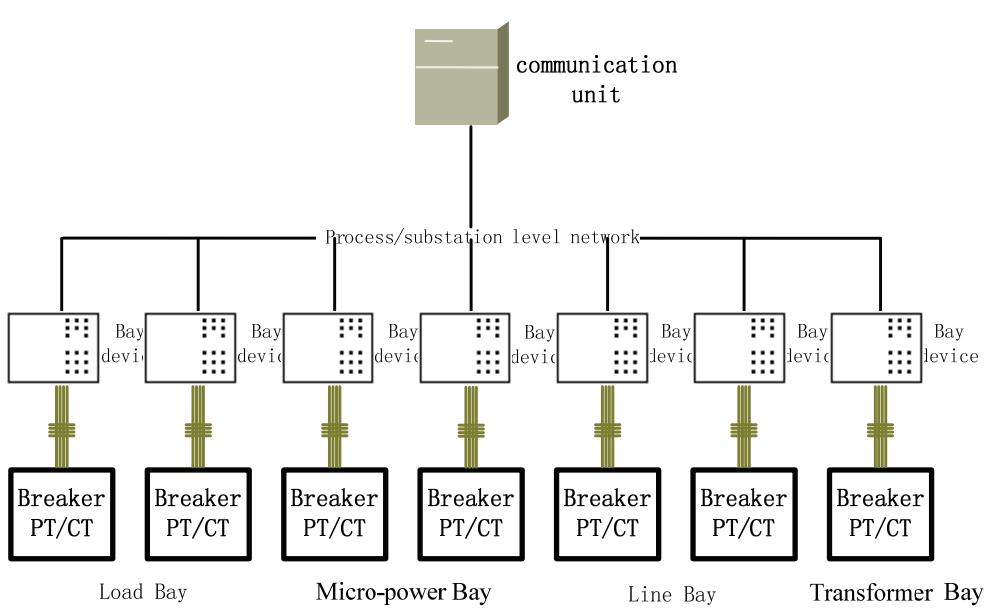

Figure 3 Wide-area protection scheme

Based on the concept of differential ring, the wide area differential protection integrates the line protection and bus protection effectively, making it possible to apply the developed wide area protection device to any regional grid by merely modifying configuration parameters without modifying the program. In the meantime, when the branch line malfunctions, the basic ring related to this branch line will be blocked immediately, and the extended differential ring will be generated to eliminate this branch. Therefore, the wide area differential protection can accurately fulfill the function of failure backup protection, eliminating the possibility of maloperation.

\subsection{Distribution protection scheme}

When adopting the distribution protection scheme, the protection devices are installed in each unit. In each unit, the bus protection adopts the differential protection as main protection and overcurrent protection as backup protection. The feeder protection uses the optical fiber differential or pilot protection as main protection, and overcurrent protection as back up protection. This same scheme can be applied to the MG with large scale and 
medium importance, generally the $10 \mathrm{kV}$ MG and some of the $0,4 \mathrm{kV}$ MG.

The conceptual structure of the distribution protection system is illustrated in Fig. 3, in which four kinds of equipment are included, which are:

1) The bus protection device, which uses the differential protection as main protection.

2) The MG transformer protection device, which mainly uses the compound voltage overcurrent protection. When necessary, it will add the differential protection as main protection. Meanwhile, it integrates the function of telemetering, tele-signaling, teleregulating, tele-controlling, and equipment operation condition monitoring, etc.

3) The MG feeder protection device, which uses the optical fiber differential or the pilot protection as main protection, and the compound overcurrent protection as backup protection. In the meantime, it integrates the function of telemetering, tele-signaling, tele-regulating, tele-controlling, and equipment operation condition monitoring, etc.

This scheme combines together the process level network and station level network to form a unified station/process level network. The station/process level network implements the data association among unit protection devices, and data communication between unit protection devices and substation computers through Ethernet. The directional pilot protection and other circuit breaker position information are exchanged by the GOOSE messages, and the MMS messages are used for data exchange between unit protection devices and substation computers.

Depending on whether the pilot protection is used, the distributed protection system can be divided into two categories: First category uses the optical fiber channel based differential protection and directional pilot protection as the main fast trip protection; the other category does not use fast trip protection.

The protection operation timing coordination diagram of distributed protection scheme uses the main fast trip protection as shown in Fig. 4.

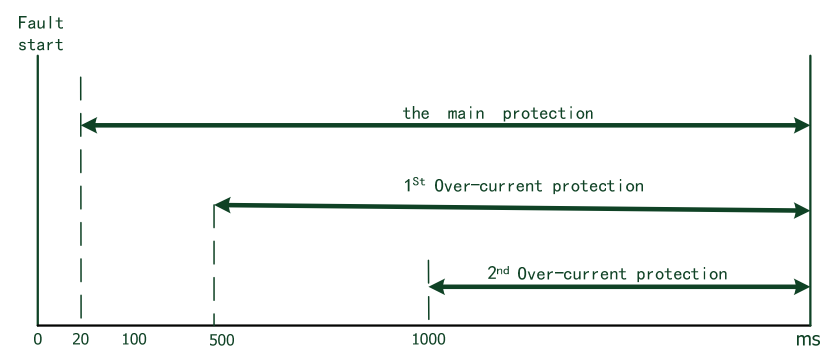

Figure 4 The protection operation time diagram of distributed protection scheme (1)

Distributed protection solutions which use main fast trip protection contain the main protection, overcurrent protection and other types of protections.

When a fault occurs within the protected area, the main protection will detect the fault in around $20 \mathrm{~ms}$, and trip circuit breaker to isolate the fault. If the fault does not disappear after $500 \mathrm{~ms}$, overcurrent protection is progressively in action according to the principles of the time coordination diagram until the fault is isolated.

The protection time coordination diagram of distributed protection scheme which uses the main fast trip protection is shown in Fig. 5.

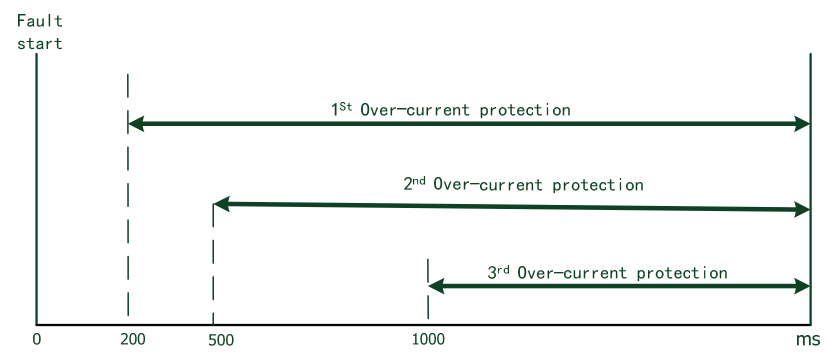

Figure 5 The protection operation time diagram of distributed protection scheme (2)

When a fault occurs within the protected area, the overcurrent protection relay will serve as the main protection and detect the fault in around $200 \mathrm{~ms}$, and isolate the fault. If the fault does not disappear after 500 $\mathrm{ms}$, the backup overcurrent protection, progressively in action, isolates the fault.

\subsection{The protection scheme with no dedicated protection device}

For the MGs with less importance or those without internal communication channels, we shall simplify the relay protection system. No dedicated protection devices need to be installed, and we only rely on the fuse, plastic casing circuit breaker and air circuit breaker for protection. This scheme applies to the MGs with less importance, generally the $0,4 \mathrm{kV}$ MG or some $10 \mathrm{kV}$ MGs in remote areas.

\section{The analysis of protection action under different protection scheme}

Assume that the new energy sources in the MG have the capacity of low voltage ride through or even zero voltage rides through. Based on the above analysis, the stability of new energy sources MG is closely related with the action time of anti-islanding protection, the action of connection points and the voltage at the connection point.

We will conduct the analysis of MG stability in two scenarios depending on the action time of anti-islanding protection of new energy sources.

1) The new energy sources use the fast trip antiislanding protection (the action time is $0,1 \mathrm{~s}$ )

2) The new energy sources do not use the fast trip antiislanding protection (the action time is $2,0 \mathrm{~s}$ )

\subsection{The stability of MG with external faults}

When the external faults occur to the MG, the stability of the MG is tested by observing the following factors: the voltage at the connection point, the action of main grid protective relays, the protective relay action of connection point and the configuration of anti-islanding protection. The analysis results are shown in Tab. 1. 
Table 1 Stability analysis of MG with external fault

\begin{tabular}{|c|c|c|c|c|}
\hline \multirow[b]{2}{*}{$\begin{array}{l}\text { The } \\
\text { voltage of } \\
\text { PCC }\end{array}$} & \multirow[b]{2}{*}{$\begin{array}{l}\text { The action } \\
\text { of the main- } \\
\text { grid } \\
\text { protection }\end{array}$} & \multirow[b]{2}{*}{$\begin{array}{l}\text { The action } \\
\text { of PCC } \\
\text { protection }\end{array}$} & \multicolumn{2}{|c|}{$\begin{array}{l}\text { Stability analysis of migro- } \\
\text { grid }\end{array}$} \\
\hline & & & $\begin{array}{c}\text { The new } \\
\text { energy } \\
\text { sources use } \\
\text { fast trip anti- } \\
\text { islanding } \\
\text { protection }\end{array}$ & $\begin{array}{l}\text { The new } \\
\text { energy } \\
\text { source does } \\
\text { not use fast } \\
\text { trip anti- } \\
\text { islanding } \\
\text { protection }\end{array}$ \\
\hline \multirow{3}{*}{$<0,5 \mathrm{pu}$} & $\begin{array}{c}\text { Fault } \\
\text { isolation } \\
\text { time }<100 \\
\mathrm{~ms}\end{array}$ & $\begin{array}{c}\text { External } \\
\text { protection or } \\
\text { PCC } \\
\text { protection } \\
\text { tripped the } \\
\text { PCC circuit } \\
\text { breaker }\end{array}$ & $\begin{array}{c}\text { Internal } \\
\text { protection } \\
\text { does not act, } \\
\text { MG turns } \\
\text { into isolated } \\
\text { operation. }\end{array}$ & $\begin{array}{c}\text { Internal } \\
\text { protection } \\
\text { does not act, } \\
\text { MG turns } \\
\text { into isolated } \\
\text { operation. }\end{array}$ \\
\hline & $\begin{array}{l}100 \mathrm{~ms}< \\
\text { Fault } \\
\text { isolation } \\
\text { time }<2 \mathrm{~s}\end{array}$ & $\begin{array}{l}\text { External } \\
\text { protection } \\
\text { orpcc } \\
\text { protection } \\
\text { trips the } \\
\text { PCC circuit } \\
\text { breaker }\end{array}$ & $\begin{array}{c}\text { The anti- } \\
\text { islanding } \\
\text { protection of } \\
\text { DG acts, and } \\
\text { MG loses } \\
\text { stablity }\end{array}$ & $\begin{array}{c}\text { Internal } \\
\text { protection } \\
\text { does not act, } \\
\text { MG turns } \\
\text { into isolated } \\
\text { operation }\end{array}$ \\
\hline & $\begin{array}{l}\text { Fault } \\
\text { isolation } \\
\text { time }>2 \mathrm{~s}\end{array}$ & $\begin{array}{l}\text { The low } \\
\text { voltage } \\
\text { protection of } \\
\text { PCC trips } \\
\text { the PCC } \\
\text { circuit } \\
\text { breaker }\end{array}$ & $\begin{array}{c}\text { The anti- } \\
\text { islanding } \\
\text { protection of } \\
\text { DG acts, and } \\
\text { MG loses } \\
\text { stablity }\end{array}$ & $\begin{array}{c}\text { The anti- } \\
\text { islanding } \\
\text { protection of } \\
\text { DG acts, and } \\
\text { MG loses } \\
\text { stablity }\end{array}$ \\
\hline \multirow{2}{*}{$>0,5 \mathrm{pu}$} & $\begin{array}{c}\text { Fault } \\
\text { isolation } \\
\text { time }>2 \mathrm{~s}\end{array}$ & $\begin{array}{l}\text { External } \\
\text { protection } \\
\text { orpcc } \\
\text { protection } \\
\text { trips the } \\
\text { PCC circuit } \\
\text { breaker }\end{array}$ & $\begin{array}{c}\text { Internal } \\
\text { protection } \\
\text { does not act, } \\
\text { MG turns } \\
\text { into isolated } \\
\text { operation }\end{array}$ & $\begin{array}{c}\text { Internal } \\
\text { protection } \\
\text { does not act, } \\
\text { MG turns } \\
\text { into isolated } \\
\text { operation }\end{array}$ \\
\hline & $\begin{array}{c}\text { Fault } \\
\text { isolation } \\
\text { time }>2 \mathrm{~s}\end{array}$ & $\begin{array}{l}\text { The low } \\
\text { voltage } \\
\text { protection of } \\
\text { PCC trips } \\
\text { the PCC } \\
\text { circuit } \\
\text { breaker }\end{array}$ & $\begin{array}{c}\text { The anti- } \\
\text { islanding } \\
\text { protection of } \\
\text { DG acts, and } \\
\text { MG loses } \\
\text { stablity }\end{array}$ & $\begin{array}{c}\text { The anti- } \\
\text { islanding } \\
\text { protection of } \\
\text { DG acts, and } \\
\text { MG loses } \\
\text { stablity }\end{array}$ \\
\hline
\end{tabular}

\subsection{The action of internal fault}

When the fault occurs within the MG, the stability of the MG is tested by observing the following factors: the voltage at the connection point, the action of master grid, the protection action of connection point and the configuration of anti-islanding protection. The analysis results are shown in Tab. 2.

\subsection{The protection configuration principle of MG}

Through the analyzing of the MG stability in different scenarios, it can be seen that the key to keep the stability of the MG is to ensure the fast action of main grid protection in the case of internal fault and the fast action of distributed network in the case of external fault.

1) The MGusess the multi-stage timing coordinated protection scheme, which combines the fast trip protection (optical fiber differential protection and directional pilot protection for example) and back-up protection (overcurrent protection and low voltage protection).

2) The communication channel between the $M G$ and the main grid uses the optical fiber differential relay as fast protection, which ensures that the fault in the main grid can be tripped rapidly and will not pose any
Table 2 Stability analysis of micro-grid when internal fault

\begin{tabular}{|c|c|c|c|c|}
\hline \multirow[b]{2}{*}{$\begin{array}{l}\text { The } \\
\text { voltage } \\
\text { of PCC }\end{array}$} & \multirow[b]{2}{*}{$\begin{array}{l}\text { The } \\
\text { action of } \\
\text { the MG } \\
\text { protection }\end{array}$} & \multirow[b]{2}{*}{$\begin{array}{l}\text { The action of } \\
\text { PCC protection }\end{array}$} & \multicolumn{2}{|c|}{$\begin{array}{c}\text { Stability analysis of migro- } \\
\text { grid }\end{array}$} \\
\hline & & & $\begin{array}{l}\text { The new } \\
\text { energy } \\
\text { sources use } \\
\text { fast trip anti- } \\
\text { islanding } \\
\text { protection }\end{array}$ & $\begin{array}{c}\text { The new } \\
\text { energy } \\
\text { source do not } \\
\text { use fast trip } \\
\text { anti- } \\
\text { islanding } \\
\text { protection }\end{array}$ \\
\hline \multirow{4}{*}{$<0,5 \mathrm{pu}$} & $\begin{array}{c}\text { Fault } \\
\text { isolation } \\
\text { time }< \\
100 \mathrm{~ms}\end{array}$ & No act & $\begin{array}{l}\text { Grid- } \\
\text { connected } \\
\text { mode }\end{array}$ & $\begin{array}{l}\text { Grid- } \\
\text { connected } \\
\text { mode }\end{array}$ \\
\hline & \multirow{2}{*}{$\begin{array}{c}100 \mathrm{~ms}< \\
\text { Fault } \\
\text { isolation } \\
\text { time }<2 \mathrm{~s}\end{array}$} & $\begin{array}{l}\text { The low voltage } \\
\text { protection or } \\
\text { over-current } \\
\text { protection of } \\
\text { PCC tripped the } \\
\text { PCC circuit } \\
\text { breaker }\end{array}$ & $\begin{array}{l}\text { The anti- } \\
\text { islanding } \\
\text { protection of } \\
\text { DG acts, and } \\
\text { MG lost } \\
\text { stablity }\end{array}$ & $\begin{array}{c}\text { MG } \\
\text { protection } \\
\text { acts } \\
\text { Microgrid } \\
\text { turns into } \\
\text { islanding } \\
\text { mode. }\end{array}$ \\
\hline & & No act & $\begin{array}{c}\text { The anti- } \\
\text { islanding } \\
\text { protection of } \\
\text { DG acts, and } \\
\text { MG lost } \\
\text { stablity } \\
\end{array}$ & $\begin{array}{l}\text { MG } \\
\text { protection } \\
\text { acts. }\end{array}$ \\
\hline & $\begin{array}{c}\text { Fault } \\
\text { isolation } \\
\text { time }>2 \mathrm{~s}\end{array}$ & $\begin{array}{l}\text { The low voltage } \\
\text { protection or } \\
\text { over-current } \\
\text { protection of } \\
\text { PCC tripped the } \\
\text { PCC circuit } \\
\text { breaker }\end{array}$ & $\begin{array}{l}\text { The anti- } \\
\text { islanding } \\
\text { protection of } \\
\text { DG acts, and } \\
\text { MG lost } \\
\text { stablity }\end{array}$ & $\begin{array}{l}\text { The anti- } \\
\text { islanding } \\
\text { protection of } \\
\text { DG acts, and } \\
\text { MG lost } \\
\text { stablity }\end{array}$ \\
\hline \multirow[b]{2}{*}{$>0,5 \mathrm{pu}$} & $\begin{array}{c}\text { Fault } \\
\text { isolation } \\
\text { time }<2 \mathrm{~s} \\
\end{array}$ & No act & $\begin{array}{c}\text { Grid- } \\
\text { connected } \\
\text { mode }\end{array}$ & $\begin{array}{c}\text { Grid- } \\
\text { connected } \\
\text { mode }\end{array}$ \\
\hline & $\begin{array}{c}\text { Fault } \\
\text { isolation } \\
\text { time }>2 \mathrm{~s}\end{array}$ & $\begin{array}{l}\text { The low voltage } \\
\text { protection of } \\
\text { PCC tripped the } \\
\text { PCC breaker }\end{array}$ & $\begin{array}{c}\text { The anti- } \\
\text { islanding } \\
\text { protection of } \\
\text { DG acts, and } \\
\text { MG lost } \\
\text { stablity } \\
\end{array}$ & $\begin{array}{c}\text { The anti- } \\
\text { islanding } \\
\text { protection of } \\
\text { DG acts, and } \\
\text { MG lost } \\
\text { stablity } \\
\end{array}$ \\
\hline
\end{tabular}

threat to the protective devices in the MG.

3 ) At the connection point, the voltage protection and frequency protection are used to isolate the fault within the main grid and the MG.

4) The anti-islanding protection configuration of the new energy source inverter is set according to the requirement of local grid corporation. Unless there are special requirements, it is suggested that the fast anti-islanding protection shall be disabled, and the action time of low voltage protection and overfrequency/under-frequency protection set at $2,0 \mathrm{~s}$.

5) If the fault occurs within the main grid, the automation system of the main grid will trip the circuit breaker through remote tripping. After the power supply in the main grid is restored, the MG energy management system (the mode controller) will restore the mode from isolated operation to connected operation, thus restarting the connected MG.

6) In order to guarantee the reliable operation of MG, it is required that the new energy sources in the $\mathrm{MG}$ shall possess the function of low voltage ride through and it is suggested adopting the new energy sources generating equipment with zero voltage ride through capability. 


\section{Conclusion}

With the popularity of $\mathrm{MG}$ in more and more engineering projects, the relay protection system of the MG has attracted ever increasing attention. Based on a thorough discussion of the fault characteristics of the distribution of new energy sources, this paper analysed the applicability of several protection schemes in $\mathrm{MG}$, which are the overcurrent protection, distance protection, differential protection, pilot protection and voltage and frequency protection. In the final part of the paper, the paper proposed three relay protection schemes for different kinds of MGs and discussed the reliability of MG in each protection scheme.

\section{Acknowledgements}

This work was supported in part by The National Natural Science Foundation of China (51177058) and the State Grid Corporation of China research plan 2011. The authors would like to thank The National Natural Science Foundation of China and the State Grid Corporation of China for the financial support to carry out this research work.

\section{References}

[1] Ritwik Majumder; Arindam Ghosh; Gerard Ledwich; Firuz Zare. Power Management and Power Flow Control with Back-to-Back Converters in a Utility Connected Microgrid. // IEEE Trans. on Power System. 25, 2(2010), pp. 821-834.

[2] Lasseter, R. H.; Eto, J. H.; Schenkman, B.; Stevens, J.; Klapp, D.; Linton, E.; Hurtado, H.; Roy, J. CERTS Microgrid Laboratory Test Bed. // IEEE Trans. on Power Delivery. 26, 1(2011), pp. 325-332.

[3] Lu Zongxiang; Wang Caixia; Min Yong, et al. Overview on microgrid research. // Automation of Electric Power Systems. 31, 19(2007), pp. 25- 34.

[4] Wang Yi; Zhang Lirong; Li Heming; Liu Junpeng. Hierarchical Coordinated Control of Wind Turbine-based DC Microgrid. // Proceedings of the CSEE. 33, 4(2013).

[5] Miao Yuancheng; Cheng Haozhong; Gong Xiaoxue; Wang Lifeng; Yao Liangzhong; Bazargan Masoud. Evaluation of a Distribution Network Connection Mode Considering Micro-grid. // Proceedings of the CSEE. Vol. 33, pp. 17-23, 28 Jan. 2012

[6] Yang Zhangang; Wang Chengshan; Che Yanbo. A small scale microgrid system with flexible modes of operation. // Automation of Electric Power Systems. 33, 14(2009), pp. 89-98.

[7] Zhao Bo; Zhang Xuesong; Li Peng; Wang Ke; Chen Jian; Li Fengbing. Optimal Design and Application of Energy Storage System in Dongfushan Island Stand-alone Microgrid. // Automation of Electric Power Systems. 37, 1(2013), pp. 161-167.

[8] Nikkhajoei, H; Lasseter, R. H. Microgrid protection [C]. // Power Engineering Society General Meeting. Tampa, USA, 2007, pp. 1-6.

[9] Baran, M. E.; El-Markaby, I. Fault analysis on distribution feeders with distributed generators. // IEEE Transactions on Power Systems. 20, (2005), pp. 1757-1764.

[10] Yao Jun; Liao Yong; Li Hui. Low Voltage Ride-through Control of Doubly-fed Induction Generator Wind Turbines with a Series Grid-side Converter. // Automation of Electric Power Systems. 34, 6(2010), pp. 98-103.

[11] Xu Jianbing; Jiang Quanyuan; Shi Qingjun. Coordinated Control of Voltage Ride Through for DFIG Wind Turbine
Systems Using Energy-based DVR. // Automation of Electric Power Systems. 37, 4(2013), pp. 14-20.

[12] IEEE STD 929-2000. IEEE Recommended Practice for Utility Interface of Photovoltaic (PV) Systems. New York: The Institute of Electrical and Electronics Engineers, 2002

[13] Laaksonen Hannu Jaakko. Protection Principles for Future Micro-grids. // IEEE Trans. on Power Electronics. 25, 12(2010), pp. 2910-2918.

[14] Sortomme Eric, Venkata S. S., Mitra Joydeep. Microgrid Protection Using Communication-Assisted Digital Relays. // IEEE Trans. on Power Delivery. 25, 4(2010), pp. 27892796.

[15] Ustun, T. S.; Ozansoy, C.; Zayegh, A. Fault Current Coefficient and Time Delay Assignment for Microgrid Protection System with Central Protection Unit. // IEEE Transactions on Power Systems. 28, 2(2013), pp. 598-606.

[16] H. Laaksonen. Protection principles for future microgrids. // IEEE Trans. Power Electron. 25, 12(2011).

[17] Vieira, J. C. M. Performance of frequency relays for distributed generation protection. // IEEE Trans. Power Del. 21, (2006), pp. 1120-1127.

[18] Mahat, P.; Zhe Chen; Bak-Jensen, B.; Bak, C. L. A Simple Adaptive Overcurrent Protection of Distribution Systems with Distributed Generation. // IEEE Transactions on Smart Grid. 2, 3(2011), pp. 428-437.

[19] Wang Xiao-Ping; Yu Yong-Yang, Li Yang. Design and implementation of microgrid protection systems. // Electric Power. 44, 2(2011), pp. 78-81.

[20] Li Yong-Li; Jin Qiang; Li Bo-Tong; Li Zhong-Zhou. Application of Inverse-Time Overcurrent Protection Based on Low Voltage Acceleration in Micro-Grid. // Journal of Tianjin University (Science and Technology). 44, 11(2011), pp. 955-960.

[21] Wu Zaijun; Zhao Shanglin; Hu Minqiang; Dou Xiaobo. Branch Directional Variation Protection of AC Microgrid. // Proceedings of the CSEE. 32, 25(2012), pp. 158-166.

[22] Zhu Haobin; Wu Zaijiun; Dou Xiaobo; Fei Ke; Lu Jinfeng. Hierarchical Coordinative Protection of Microgrid. // Power System Technology. 37, 1(2013).

[23] Bialasiewicz, J. T. Renewable Energy Systems with Photovoltaic Power Generators: Operation and Modeling. // IEEE Transactions on Industrial Electronics. 55, 7(2008), pp. 2752-2758

[24] Karki, R.; Po Hu; Billinton, R. A simplified wind power generation model for reliability evaluation. // IEEE Transactions on Energy Conversion. 21, 2(2006), pp. 533540.

[25] Li Wang; Guang-Zhe Zheng. Analysis of a Microturbine Generator System Connected to a Distribution System Through Power-Electronics Converters. // IEEE Transactions on Sustainable Energy. 2, 2(2011), pp. 159166.

[26] Jemei, S.; Hissel, D.; Pera, M.-C.; Kauffmann, J. M. A New Modeling Approach of Embedded Fuel-Cell Power Generators Based on Artificial Neural Network. // IEEE Transactions on Industrial Electronics. 55, 1(2008), pp. 437-447.

[27] Mercier, P.; Cherkaoui, R.; Oudalov, A. Optimizing a Battery Energy Storage System for Frequency Control Application in an Isolated Power System. // IEEE Transactions on Power Systems. 24, 3(2009), pp. 14691477. 


\section{Authors' addresses}

Zhaoyun Zhang, Ph.D.

State Key Laboratory of Advanced Electromagnetic Engineering and Technology, Huazhong University of Science \& Technology, Wuhan 430074, China

E-mail: zhangzhaoyun@sina.com

Wei Chen, Associate Professor

State Key Laboratory of Advanced Electromagnetic Engineering and Technology, Huazhong University of Science \& Technology

Wuhan 430074, China

E-mail: weichen@mail.hust.edu.cn

\section{Zhe Zhang, Professor}

State Key Laboratory of Advanced Electromagnetic Engineering and Technology, Huazhong University of Science \& Technology Wuhan 430074, China

E-mail: zz mail2002@163.com 